\title{
The southernmost range limit for the hidden angelshark Squatina occulta
}

\author{
María Lourdes Estalles ${ }^{1,2^{*}}$, Gustavo E. Chiaramonte ${ }^{2}$, Vicente V. Faria ${ }^{3}$, Diego C. Luzzatto ${ }^{1,2}$ \\ and Juan M. Díaz de Astarloa'
}

\begin{abstract}
Background: Angelsharks (Genus Squatina) are distributed in the southern Southwest Atlantic Ocean between southeastern Brazil and central Patagonia. The endangered hidden angelshark Squatina occulta is reported in the literature as ranging from Espírito Santo, Brazil to Southern Uruguay. Its presence in Argentine waters has been suspected but not verified so far. This study describes and analyzes a specimen of $\mathrm{S}$. occulta found in Puerto Quequén $38^{\circ} 40^{\prime} \mathrm{S}-58^{\circ} 50^{\prime} \mathrm{W}$, Buenos Aires Province, Argentina.

Results: An immature male of $578 \mathrm{~mm}$ total length and 1,450 $\mathrm{g}$ was collected from commercial landings of the bottom trawl fishery of Puerto Quequén. The specimen exhibited the coloration pattern, dermal denticle distribution, and tooth formula characteristic of S. occulta.

Conclusions: Squatina guggenheim and S. argentina are already known to occur off Puerto Quequén. The present finding confirms the presence of a third species of angelshark in Argentina and constitutes the southernmost record of S. occulta.
\end{abstract}

Keywords: Chondrichthyes, Elasmobranchii, Squatinidae, Southwest Atlantic Ocean

\section{Background}

The genus Squatina Dumeril 1806 is composed of 20 species of angelsharks (Weigmann 2016). The species of this genus are unique among sharks due to their ray-like features. Their bodies are flattened dorso-ventrally with broad pectoral fins, a terminal mouth, and eyes and spiracles located dorsally. They also have a long and flattened tail without an anal fin. Unlike rays, however, their gill slits are located laterally on the head and forward of the pectoral-fin origins (Last \& White 2008).

Angelsharks are distributed in the southern Southwest Atlantic Ocean between southeastern Brazil and central Patagonia (Cousseau \& Figueroa 2001; Vooren \& Klippel 2005). They are found from the inshore to the upper continental slopes (Vooren \& Klippel 2005). The similarity of external morphology among species led to different

\footnotetext{
*Correspondence: mariluestalles@gmail.com

'Instituto de Investigaciones Marinas y Costeras (IIMYC- CONICET);

Departamento de Biología, Facultad de Ciencias Exactas y Naturales,

Universidad Nacional de Mar del Plata, Rodríguez Peña 4046, 7600 Buenos

Aires, Argentina

${ }^{2}$ Estación Hidrobiológica de Puerto Quequén, Museo Argentino de Ciencias Naturales "Bernardino Rivadavia" MACN- CONICET, Buenos Aires, Argentina Full list of author information is available at the end of the article
}

taxonomic hypothesis and misidentifications in previous literature (Cousseau \& Figueroa 2001; Cousseau 1973; Vaz \& de Carvalho 2013; Faria et al. 2014). Recently, the taxonomy of these species was revised and clarified and, Squatina guggenheim Marini 1936, S. argentina (Marini 1930) and S. occulta Vooren \& da Silva 1991 are recognized as valid species in this area (Vaz \& de Carvalho 2013). Genetic analysis supports the differentiation of these three species (Solé-Cava \& Levy 1987; Solé-Cava et al. 1983; Furtado-Neto et al. 2002; Falcão et al. 2014).

Despite the recent clarifications of the taxonomy, problems concerning the distribution and occurrence of angelsharks in the region still persist, at least for $S$. occulta. The hidden angelshark S. occulta is reported in the literature as ranging from Espírito Santo State, Brazil to southern Uruguay in the Argentinean-Uruguayan Common Fishing Zone (Vaz \& de Carvalho 2013; Milessi et al. 2001). Even though $S$. occulta's presence was proposed along the Argentinean shelf (to $45^{\circ} \mathrm{S}$ ), this could not be verified so far (Cousseau \& Figueroa 2001; Vooren \& Klippel 2005; Vaz \& de Carvalho 2013). The present study reports and describes a specimen of this species found in 


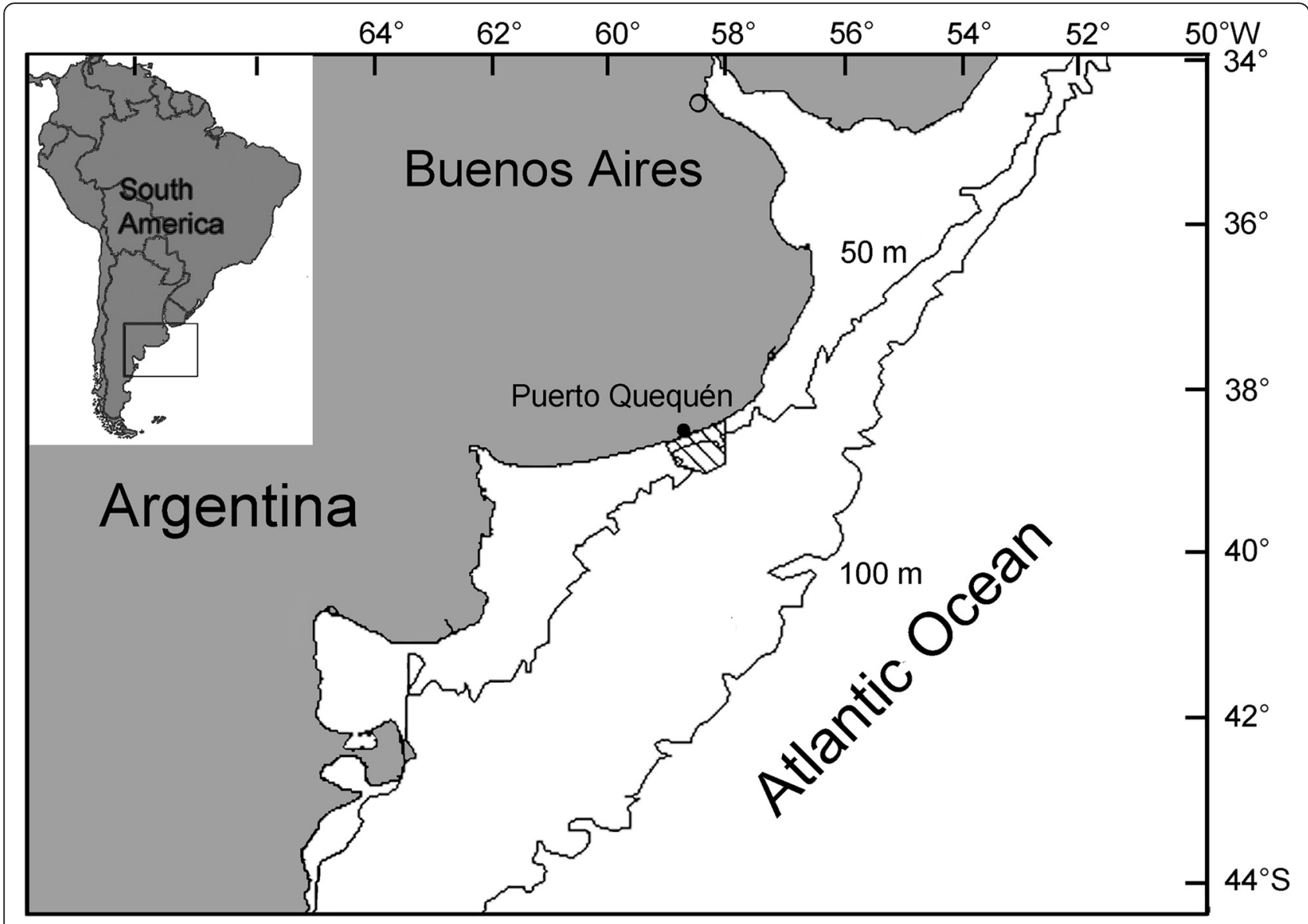

Fig. 1 Study Area. Location of Puerto Quequén, Necochea, Buenos Aires Province Argentina. In striped the operational area of the bottom trawl fishery

the area of Puerto Quequén, Necochea, Buenos Aires Province, Argentina.

\section{Methods}

\section{Sampling site}

Puerto Quequén (38 $40^{\prime} \mathrm{S}$ - $58^{\circ} 50^{\prime} \mathrm{W}$; Fig. 1) is a grain export port located in Necochea, Buenos Aires Province, northern Argentina which also harbors a small fishery. Its fleet is composed of 14 vessels which operate in an arc of 30 nautical miles from the coastline with the port as its focal point. The primary fishing gear employed is the bottom trawl. Landings are approximately 3,000 metric tons annually. Puerto Quequén is the second largest fishing port in Argentina with respect to commercial landings of angelsharks and contributes, on average, $10 \%$ of the country's total catch (period 2006 to 2012) (Sánchez et al. 2012; Navarro et al. 2014). As in other fisheries of Argentina, angelsharks are recorded in a common category without discrimination between species.

\section{Specimen}

Squatina occulta was sampled on 15 March 2015 during fishery landings at Puerto Quequén. The specimen was

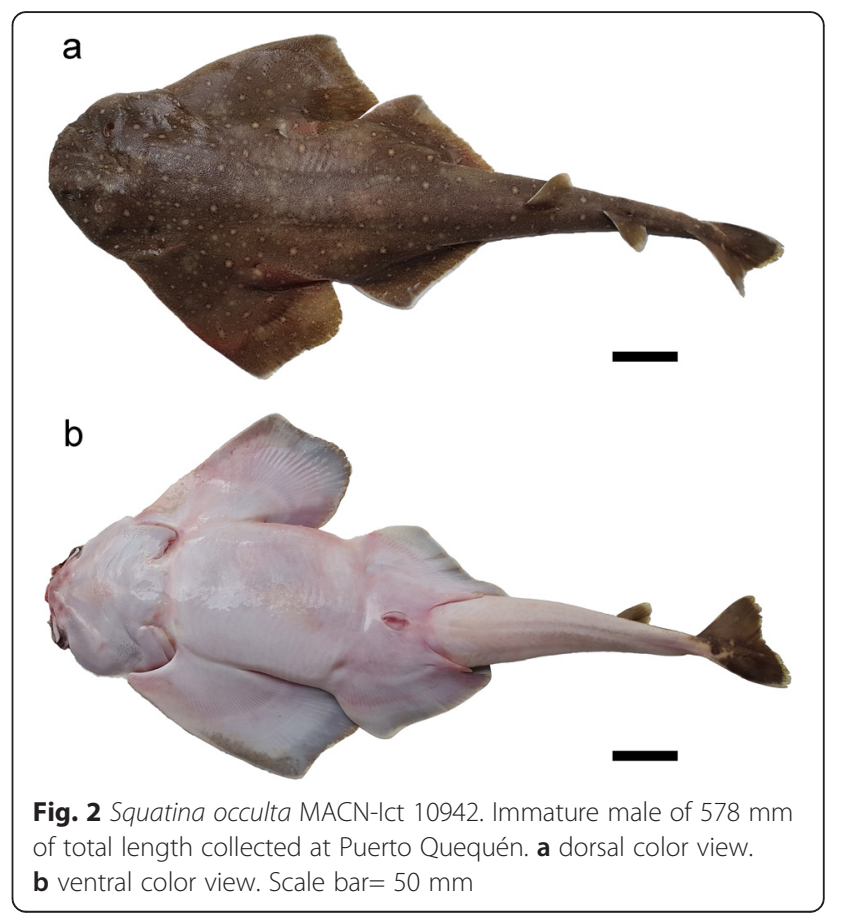


Table 1 Morphological measurements of Squatina occulta MACN-Ict 10942 collected at Puerto Quequén

\begin{tabular}{|c|c|c|c|c|c|}
\hline $\begin{array}{l}\text { Morphometric } \\
\text { character }\end{array}$ & $\mathrm{mm}$ & $\% \mathrm{TL}$ & $\begin{array}{l}\text { Morphometric } \\
\text { character }\end{array}$ & $\mathrm{mm}$ & $\% \mathrm{TL}$ \\
\hline Total length (TL) & 578 & & $\begin{array}{l}\text { Clasper inner } \\
\text { length }\end{array}$ & 65.2 & 11.3 \\
\hline Pre-caudal length & 493 & 85.3 & $\begin{array}{l}\text { Clasper outer } \\
\text { length }\end{array}$ & 9.8 & 1.7 \\
\hline Pre-dorsal length & 371 & 64.2 & $\begin{array}{l}\text { Clasper base } \\
\text { width }\end{array}$ & 5.0 & 0.9 \\
\hline Pre-pectoral length & 122 & 21.1 & $\begin{array}{l}\text { Snout-cloaca } \\
\text { length }\end{array}$ & 287 & 49.7 \\
\hline Pre-pelvic length & 239 & 41.3 & $\begin{array}{l}\text { Cloaca-caudal } \\
\text { length }\end{array}$ & 289 & 50 \\
\hline Pre-branchial length & 88.4 & 15.3 & & & \\
\hline Pre-spiracular length & 52.4 & 9.1 & & & \\
\hline Pre-ocular length & 31.5 & 5.4 & & & \\
\hline Pre-orbital length & 23.7 & 4.1 & & & \\
\hline Head width & 119.8 & 20.7 & & & \\
\hline Orbital head width & 74.7 & 12.9 & & & \\
\hline Spiracular head width & 116.2 & 20.1 & & & \\
\hline Mouth width & 76.5 & 13.2 & & & \\
\hline Head height & 38.6 & 6.7 & & & \\
\hline Interorbital distance & 48.2 & 8.3 & & & \\
\hline Eye length & 11.1 & 1.9 & & & \\
\hline Eye width & 7.7 & 1.3 & & & \\
\hline Eye-spiracle distance & 15 & 2.6 & & & \\
\hline Internarial distance & 36.5 & 6.3 & & & \\
\hline Interspiracular distance & 45.5 & 7.9 & & & \\
\hline Spiracle length & 13.1 & 2.3 & & & \\
\hline Intergill width & 14.8 & 9.8 & & & \\
\hline Intergill length & 56.6 & 2.6 & & & \\
\hline Interdorsal distance & 36.9 & 6.4 & & & \\
\hline Dorsal-caudal distance & 38.8 & 6.7 & & & \\
\hline Pectoral-pelvic distance & 49.1 & 8.5 & & & \\
\hline $\begin{array}{l}\text { Pelvic (origin)-caudal } \\
\text { distance }\end{array}$ & 253 & 43.8 & & & \\
\hline Pelvic-caudal distance & 190 & 32.9 & & & \\
\hline Width at pectoral origins & 85.5 & 14.8 & & & \\
\hline Trunk width & 102.2 & 17.7 & & & \\
\hline Tail width & 61.5 & 10.6 & & & \\
\hline Tail height & 27 & 4.7 & & & \\
\hline Pectoral-fin length & 177 & 30.6 & & & \\
\hline Pectoral-fin anterior margin & 152 & 26.3 & & & \\
\hline Pectoral-fin base length & 55.9 & 9.7 & & & \\
\hline Pectoral-fin width & 98.6 & 17.1 & & & \\
\hline Pectoral-fin inner margin & 91.4 & 15.8 & & & \\
\hline Pelvic-fin length & 128.3 & 22.2 & & & \\
\hline
\end{tabular}

Table 1 Morphological measurements of Squatina occulta MACN-Ict 10942 collected at Puerto Quequén (Continued)

\begin{tabular}{lll}
\hline Pelvic-fin width & 81.7 & 14.1 \\
Pelvic-fin inner margin & 69.2 & 12.0 \\
First dorsal-fin base length & 22.9 & 4.0 \\
First dorsal-fin anterior & 45.9 & 7.9 \\
margin & & \\
First dorsal-fin height & 29.5 & 5.1 \\
First dorsal-fin inner margin & 16.8 & 2.9 \\
$\begin{array}{l}\text { Second dorsal-fin base } \\
\text { length }\end{array}$ & 21.1 & 3.7 \\
$\begin{array}{l}\text { Second dorsal-fin anterior } \\
\text { margin }\end{array}$ & 42.5 & 7.4 \\
$\begin{array}{l}\text { Second dorsal-fin height } \\
\text { Second dorsal-fin inner }\end{array}$ & 26.5 & 4.6 \\
margin & 17.5 & 3 \\
Dorsal caudal-fin margin & 64.3 & 11.1 \\
$\begin{array}{l}\text { Preventral caudal -fin } \\
\text { margin }\end{array}$ & 79.4 & 13.7 \\
Caudal-fin height & 76.3 & 13.2 \\
\hline
\end{tabular}

preserved at $-20{ }^{\circ} \mathrm{C}$ for $24 \mathrm{~h}$ and identified after defrosting. Identification and morphological measurements followed (Last \& White 2008; Vaz \& de Carvalho 2013). The specimen was deposited in the fish collection of the División Ictiología of the Museo Argentino de Ciencias Naturales "Bernardino Rivadavia" and catalogued as MACN-Ict 10942.

\section{Results}

The specimen was determined to be an immature male of $578 \mathrm{~mm}$ TL and 1,450 g. Anterior margin of the pectoral fin slightly convex with its posterior tip not reaching the external angle of the pelvic fin (Fig. 2a). Brown dorsal color pattern, with numerous white to yellowish rounded spots over the entire surface and larger white spots surrounded by many blackish dots located at the mid-dorsal region of the body (Fig. 2a). The larger white

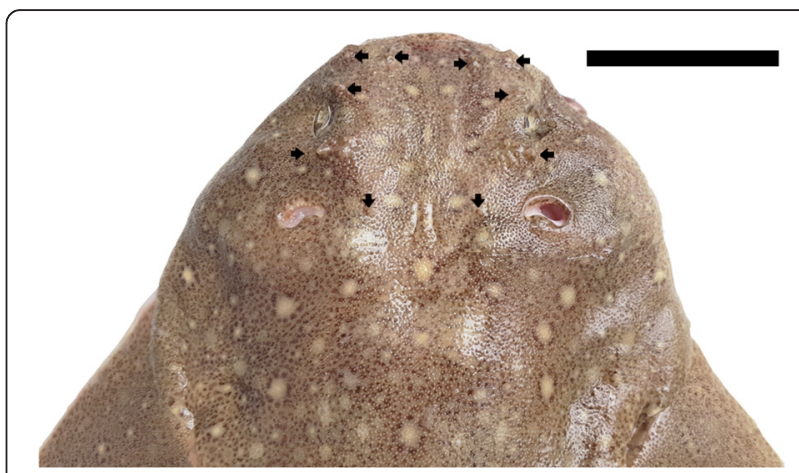

Fig. 3 Dorsal view of head exhibiting enlarged dermal denticles. Scale bar $=50 \mathrm{~mm}$ 
spots ranged from $7.0 \pm 0.7 \mathrm{~mm}$ wide over the head and trunk to $8.2 \pm 0.8 \mathrm{~mm}$ wide over the trunk. Posterior margin of the pectoral fin mottled, and the tail displayed a creamy coloration pattern. The rest of the ventral surface was white (Fig. 2b). Morphological measurements are provided in Table 1.

Dermal denticles on dorsal midline and pectoral fins similar in size to those from the remaining regions of the body with the exception of slightly enlarged dermal denticles near the origin of the first dorsal fin. Above the head enlarged dermal denticles where found symmetrically organized (Fig. 3). A pair of enlarged denticles between the spiracles, one on each side of the dorsal midline of the body. A cluster of four or five enlarged denticles posterior to each eye, two of them noticeably larger than the others. Three enlarged denticles anterior to each eye, one on the anterior edge of the eye, one between the eyes and the nostrils, and the most anterior one nearly reaching the snout (Fig. 3).

Teeth smaller in the upper jaw than in lower jaw and arranged in 18 longitudinal upper rows and in 20 lower rows. Tooth formula: 9-9/10-10, respectively.

\section{Discussion}

The specimen collected at Puerto Quequén confirms the presence of S. occulta in Argentina. The most distinctive characteristics of the individual found were its coloration pattern, the relative size of the spots, and the distribution pattern of enlarged dermal denticles. The morphological measurements were in the range of the values reported for $S$. occulta even though they were not useful for discriminating among Southwestern Atlantic species, as pointed out by the authors (Vaz \& de Carvalho 2013).

This individual was distinguished from S. guggenheim and $S$. argentina by its brown background color with several rounded yellowish spots on the dorsal surface (spot size ranging from 0.54 to 0.81 eye-length), the larger spots surrounded by many small blackish dots; the slightly convex anterior margin of the pectoral fin; absence of enlarged dermal denticles and enlarged dermal denticles symmetrically distributed on the head with a pair of them located between spiracles.

\section{Conclusion}

Squatina guggenheim and S. argentina are already known to occur off Puerto Quequén, Necochea (Marini 1930; Marini 1936). The present finding confirms the presence of a third species of angelshark in Argentina and constitutes the southernmost record of S. occulta.

\section{Abbreviations}

TL, total length; g, grams; mm, milimeters; MACN, Museo Argentino de Cienicas Naturales "Bernardino Rivadavia"

\section{Acknowledgements}

We thank Roque Bruno, José Renaudo and David Iglesias, as well as their staff at the fish processing plants, for kindly allowing us to sample angelsharks. We also would like to acknowledge the fishermen of Puerto Quequén, Necochea for granting us access to their catch falta el verbo. We are grateful to Aspen Padilla for language review.

\section{Funding}

The study was performed during the Postdoctoral fellowship granted by Consejo Nacional de Investigaciones Científicas y Técnicas- CONICET to María Lourdes Estalles.

\section{Availability of data and materials}

The specimen analyzed in the present study is available in the fish collection of the División Ictiología of the Museo Argentino de Ciencias Naturales "Bernardino Rivadavia", catalogued as MACN-Ict 10942

\section{Authors' contributions}

MLE and DCL collected the specimen, identified the specimen and performed the measurements, took the photograph and prepared the figures. MLE analyzed the data. MLE, WF, GEC, JMDA prepared the manuscript. All the authors corrected the draft, read and approved the final manuscript.

\section{Competing interests}

The authors declare that they have no competing interests.

\section{Author details}

'Instituto de Investigaciones Marinas y Costeras (IIMYC- CONICET); Departamento de Biología, Facultad de Ciencias Exactas y Naturales, Universidad Nacional de Mar del Plata, Rodríguez Peña 4046, 7600 Buenos Aires, Argentina. ${ }^{2}$ Estación Hidrobiológica de Puerto Quequén, Museo Argentino de Ciencias Naturales "Bernardino Rivadavia" MACN- CONICET, Buenos Aires, Argentina. ${ }^{3}$ Departamento de Biologia, Universidade Federal do Ceará, Fortaleza, Brazil.

Received: 8 June 2016 Accepted: 10 June 2016

Published online: 01 August 2016

\section{References}

Cousseau MB, Figueroa DE. Las especies del género Squatina en aguas argentinas (Pisces: Elasmobranchii: Squatinidae). Neotropica. 2001;47:85-6.

Cousseau MB. Taxonomía y biología del pez ángel, Squatina argentina Marini (Pisces, Squatinidae). Physis (A). 1973;32 Suppl 84:175-95.

Falcão LHO, Furtado-Neto MAA, Maggioni R, Faria W. Prospective molecular markers for the identification of illegally traded angelsharks (Squatina) and dolphin (Sotalia guianensis). Genet Mol Res. 2014;13:9710-7.

Faria W, Chiaramonte GE, van Oijen MJP. Publication date and author spelling for the hidden angelshark Squatina occulta. J Fish Biol. 2014;84:1185-7.

Furtado-Neto M, Carr S. Molecular genetics of some Brazilian sharks. The IUCN/ SSC Shark Specialist Group, Shark News. 2002;14. Available at http:// ufdcimages.uflib.ufl.edu/UF/00/09/04/96/00014/Binder14.pdf.

Last PR, White WT. Three new angel sharks (Chondrichthyes: Squatinidae) from the Indo-Australian region. Zootaxa. 2008;1734:1-26.

Marini TL. Nueva especie de pez ángel Rhina argentina sp. Physis. 1930;10:5-7.

Marini TL. Revisión de las especies de la familia Squatinidae en las aguas argentinas (S. quggenheim sp.). Physis. 1936;12:19-30.

Milessi A, Vögler R, Bazzino G. Identificación de tres especies del género Squatina (Chondrichthyes, Squatinidae) en la Zona Común de Pesca ArgentinoUruguaya (ZCPAU). Gayana (Concepción). 2001;65 Suppl 2:167-72.

Navarro G, Rozycki V, Monsalvo M. Estadísticas de la pesca marina en la Argentina: evolución de los desembarques 2008-2013. Ciudad Autónoma de Buenos Aires: Ministerio de Agricultura, Ganadería y Pesca de la Nación; 2014

Sánchez RP, Navarro G, Rozycki V. Estadísticas de la pesca marina en la Argentina: evolución de los desembarques 1898-2010. Ciudad Autónoma de Buenos Aires: Ministerio de Agricultura, Ganadería y Pesca de la Nación; 2012

Solé-Cava AM, Levy JA. Biochemical evidence for a third species of angel shark (Squatina) off the east coast of South America. Biochem Syst Ecol. 1987;15:139-44. 
Solé-Cava AM, Vooren CM, Levy JA. Isozymic differentiation of two sibling species of Squatina (Chondrichthyes) in South Brazil. Com Biochem Phys. 1983;75:354-8.

Vaz DFV, de Carvalho MR. Morphological and taxonomic revision of species of Squatina from the Southwestern Atlantic Ocean (Chondrichthyes: Squatiniformes: Squatinidae). Zootaxa. 2013;3695 Suppl 1:1-81.

Vooren CM, Klippel S. Ações para a conservação de tubarões e raias no sul do Brasil. Porto Alegre: Igaré; 2005.

Weigmann S. Annotated checklist of the living sharks, batoids and chimaeras (Chondrichthyes) of the world, with a focus on biogeographical diversity. J Fish Biol. 2016. doi:10.1111/jfb.12874.

Submit your next manuscript to BioMed Central and we will help you at every step:

- We accept pre-submission inquiries

- Our selector tool helps you to find the most relevant journal

- We provide round the clock customer support

- Convenient online submission

- Thorough peer review

- Inclusion in PubMed and all major indexing services

- Maximum visibility for your research

Submit your manuscript at www.biomedcentral.com/submit
Biomed Central 